\title{
Bagaimana Peran Tata Kelola Perusahaan Dalam Hubungan Antara Manajemen Laba Dan Risiko Idiosinkratik di Indonesia?
}

\author{
Amrie Firmansyah $^{1}$ dan Nopriyanto Hady Suhanda ${ }^{2}$ \\ ${ }^{1}$ Jurusan Akuntansi, Politeknik Keuangan Negara STAN \\ ${ }^{2}$ Badan Kebijakan Fiskal \\ Email Address: \\ $\underline{\text { amrie@ pknstan.ac.id }}^{1}$, nopriyantohadys@gmail.com ${ }^{2}$
}

\begin{abstract}
This study aims to investigate the association of accrual earnings management and real earnings management with idiosyncratic risk. In addition, this study also examines the role of corporate governance as a moderator. This study employs a quantitative approach with secondary data obtained from www.idx.co.id and www.finance.yahoo.com in financial report data and company stock prices from 2012 to 2017 are listed on the Indonesia Stock Exchange. The total sample amounted to 244 observations based on purposive sampling. Hypothesis testing is conducting by employing multiple linear regression analysis for panel data. This study suggests that real earnings management and accrual earnings management are positively associated with idiosyncratic risk. This study also finds that corporate governance does not weaken the positive association between accrual earnings management and real earnings management with idiosyncratic risk. This study indicates that the Indonesian Financial Services Authority should coordinate with the Indonesian Institute of Accountants to reduce earnings management actions in the Indonesian Capital Market.
\end{abstract}

Keywords: Internal Risk, Earnings Quality, Governance, Disclosure.

Abstrak: Penelitian ini bertujuan untuk menginvestigasi hubungan manajemen laba akrual dan manajemen laba riil dengan risiko idiosinkratik. Selain itu, penelitian ini juga menguji peran tata kelola perusahaan sebagai pemoderasi. Penelitian ini menggunakan pendekatan kuantitatif dengan data sekunder yang bersumber dari www.idx.co.id dan www.finance.yahoo.com berupa data laporan keuangan dan harga saham perusahaan tahun 2012 sampai tahun 2017 yang listed di Bursa Efek Indonesia. Total sampel penelitian ini berjumlah 244 observasi berdasarkan purposive sampling. Pengujian hipotesis dilakukan dengan menggunakan analisis regresi linier berganda untuk data panel. Penelitian ini menyimpulkan bahwa manajemen laba riil dan manajemen laba akrual berpengaruh positif terhadap risiko idiosinkratik. Penelitian ini juga menemukan bahwa tata kelola perusahaan gagal memperlemah hubungan antara manajemen laba dan risiko idiosinkratik. Hasil penelitian ini menyarankan kepada Otoritas Jasa Keuangan perlu berkoordinasi dengan Ikatan Akuntan Indonesia dalam upaya untuk menurunkan tindakan manajemen laba di Pasar Modal Indonesia.

Kata kunci: Risiko Internal, Kualitas Laba, Tata Kelola, Pengungkapan. 


\section{PENDAHULUAN}

Dalam investasi, investor menghadapi paradoks hubungan antara risiko dan tingkat pengembalian (Bowman, 1980). Selain itu, terdapat risiko investasi yang harus ditanggung oleh investor. Di pasar saham, investor dihadapkan pada berbagai jenis risiko. Secara umum, risiko dapat dengan mudah dikategorikan menjadi dua kelompok, risiko sistematis dan tidak sistematis (Titman et al., 2010). Risiko sistematis atau komponen risiko yang tidak dapat didiversifikasi mengukur kontribusi investasi terhadap risiko portofolio pasar (Titman et al., 2010). Sebaliknya, risiko tidak sistematis atau risiko yang dapat didiversifikasi adalah komponen yang tidak berkontribusi pada risiko portofolio pasar. Dengan kata lain, risiko tidak sistematis adalah risiko unik atau spesifik yang terkandung dalam suatu perusahaan (Firmansyah et al., 2020a). Risiko tidak sistematis juga dikenal sebagai risiko idiosinkratik.

Sejumlah penelitian dilakukan lebih memfokuskan pada risiko sistematis daripada risiko tidak sistematis (Liu et al., 2014). Investor dan sejumlah peneliti lebih memperhatikan risiko yang tidak dapat dimitigasi melalui diversifikasi (Titman et al., 2010). Namun, penelitian terkait risiko idiosinkratik sama pentingnya dengan risiko sistemik karena dipengaruhi oleh preferensi dan kebijakan yang dibuat oleh manajer. Manajer menanggapi peristiwa dan fenomena dari internal dan eksternal perusahaan melalui kebijakan. (Jammernegg dan Kischka, 2007) menyatakan bahwa preferensi risiko manajer persediaan dapat dinyatakan sebagai fungsi dari nilai keuntungan produk mengenai tingkat ketersediaan produk dan kemungkinan kerugian. Dengan demikian, intervensi manajer mempengaruhi risiko yang berasal dari internal perusahaan.

Risiko idiosinkratik merupakan ukuran yang paling tepat dalam menjelaskan risiko spesifik perusahaan karena diduga risiko tersebut muncul akibat adanya kebijakan internal tertentu. (Zhou et al., 2016) menyatakan bahwa eksplorasi risiko idiosinkratik sangat diperlukan. Pertama, investor mungkin ingin mendiversifikasi portofolio mereka untuk mengurangi risiko. Namun, mereka mungkin tidak dapat membuat portofolio yang terdiversifikasi dengan baik karena biaya transaksi dan informasi yang tidak lengkap di mana risiko idiosinkratik tidak dapat dihilangkan. Kedua, spekulan dan manajer investasi lebih memfokuskan pada risiko idiosinkratik daripada volatilitas agregat total karena mereka menargetkan yang luar biasa. Ketiga, investor institusional lebih berhati-hati dalam mengelola dana, yang mengakibatkan sensitivitas terhadap risiko idiosinkratik. Terakhir, risiko idiosinkratik menentukan peristiwa, karena peristiwa spesifik perusahaan memengaruhi harga saham individu. Oleh karena itu, pengujian risiko idiosinkratik perlu untuk diinvestigasi lebih lanjut.

Beberapa penelitian sebelumnya menguji pengaruh risiko idiosinkratik terhadap pada saham (Liu dan Di Iorio, 2012; Wang, 2013; Bozhkov et al., 2018; Qadan et al., 2019). Penelitian-penelitian tersebut yang telah dilakukan pada topik ini menggunakan data dari negara-negara maju. Sementara itu, beberapa penelitian yang menguji risiko idiosinkratik terhadap terhadap saham telah dilakukan di beberapa negara berkembang antara lain oleh (Aziz dan Anshari, 2017), (Noviayanti dan Husodo, 2017), (Chowdury dan Hossain, 2019), (Vo et al., 2020), (Anggiyanti, 2018), (Pujianto dan Wibowo, 2019), (Darmawan et al., 2017). 
Selanjutnya, penelitian yang menginvestigasi faktor-faktor yang menjelaskan risiko idiosinkratik dilakukan dengan laporan keuangan (Rajgopal dan Venkatachalam, 2011; Chang et al., 2015; Zhou et al., 2016, Firmansyah et al., 2020a), kepemilikan institusional (Chichernea et al., 2013; Firmansyah et al., 2020b), kebijakan dividen (Liu et al., 2014; Anwar et al., 2015; Firmansyah et al., 2020b), ukuran perusahaan (Liu et al., 2014; Firmansyah et al., 2020b), leverage (Liu et al., 2014), profitabilitas (Liu et al. 2014; Firmansyah et al., 2020b), kepemilikan manajerial (Tan dan Liu, 2016), aset tidak berwujud (Li et al., 2019), pengungkapan tanggung jawab sosial (Tzouvanas et al., 2020).

Pada tahun 2012, perusahaan di Indonesia mulai menerapkan International Financial Reporting Standards (IFRS) pada laporan keuangannya, menurut (Narendra dan Haryanto, 2013). Menurut (DeFond et al., 2011), penerapan standar terpadu akan meningkatkan komparabilitas laporan keuangan dan menarik lebih banyak investor. Penerapan IFRS akan menginternasionalkan pasar Indonesia kepada investor asing. Selain itu, tujuan dari konvergensi IFRS adalah untuk memungkinkan laporan keuangan memberikan informasi yang lebih valid tentang aset, kewajiban, ekuitas, pendapatan, dan beban perusahaan (Cahyati, 2011). Dengan penerapan IFRS diharapkan perusahaan dapat meningkatkan komparabilitas laporan keuangannya dan memberikan informasi yang lebih kredibel, relevan, dan andal (Cahyati, 2011). Oleh karena itu, investor membutuhkan informasi yang komprehensif mengenai perusahaan agar investor dapat mengambil keputusan investasi yang diinginkan. Namun, (Septyanto, 2013) menemukan bahwa investor Indonesia tidak menggunakan informasi dalam laporan keuangan dalam proses pengambilan keputusan. Kegunaan laporan keuangan di Indonesia belum mencapai tingkat yang optimal. Investor Indonesia, mengambil keputusan berdasarkan firasat, perspektif orang lain, pendirian diri, dan pertimbangan lainnya (Septyanto, 2013). Dengan kata lain, investor tidak menggunakan analisis fundamental dalam pengambilan keputusan. Selain itu, masalah lain yang timbul dari informasi keuangan yang disajikan belum tentu dapat digunakan sebagai pengambilan keputusan investasi. Padahal, informasi keuangan seharusnya dapat membantu investor dalam proses pengambilan keputusan investor (Godfrey, 2010).

Kualitas laporan keuangan dapat tercermin dari kualitas laba yang dihasilkan oleh perusahaan selama satu periode. (Rajgopal dan Venkatachalam, 2011) menyatakan bahwa kualitas laba yang buruk atau kualitas pelaporan keuangan yang buruk konsisten dengan laporan keuangan yang tidak dapat dipahami oleh penggunanya. Kualitas laba yang baik menunjukkan rendahnya indikasi praktik manajemen laba. Penyataan tersebut didukung oleh temuan oleh (Chen et al., 2012). Sejalan dengan temuan tersebut, (Chang et al., 2015) menyimpulkan bahwa perusahaan-perusahaan di AS yang melakukan manajemen laba akrual dan manajemen laba riil berpengaruh positif terhadap risiko idiosinkratik. (Zhou et al., 2016) mendokumentasikan bahwa terdapat hubungan negatif antara kualitas pelaporan keuangan dengan risiko idiosinkratik. Sementara itu, (Firmansyah et al., 2020a) menemukan bahwa kualitas laba yang ditunjukkan dengan volatilitas laba rugi tidak berpengaruh terhadap risiko idiosinkratik. (Fazil dan Ipek, 2013) mendokumentasikan bahwa dari tahun 2007 hingga 2010 di pasar negara berkembang, risiko idiosinkratik merupakan komponen yang paling signifikan dibandingkan dengan. Oleh karena itu, pengujian kualitas laba terhadap risiko idiosinkratik perlu untuk diinvestigasi lebih lanjut khususnya dengan menggunakan data perusahaan Indonesia sebagai salah satu negara berkembang. 
Penelitian ini bertujuan untuk menguji manajemen laba akrual dan manajemen laba riil terhadap risiko idiosinkratik. Penelitian (Rajgopal dan Venkatachalam, 2011), (Chen et al., 2012) menggunakan manajemen laba akrual dalam mengukur kualitas laba, sedangkan (Chang et al., 2015) menggunakan manajemen laba akrual dan manajemen laba riil dalam mengukur kualitas laba. Ketiga penelitian tersebut menggunakan data negara maju yaitu data perusahaan di AS. (Zhou et al., 2016) menggunakan manajemen laba akrual dalam mengukur kualitas laba di China, sedangkan (Firmansyah et al., 2020a) menggunakan volatilitas laba rugi triwulanan dalam mengukur kualitas laba di Indonesia. Sementara itu, penelitian ini mengukur kualitas laba dengan manajeman laba akrual dan manajemen laba riil dengan menggunakan data perusahaan Indonesia.

Selain itu, penelitian ini menggunakan peran tata kelola sebagai pemoderasi dalam hubungan antara manajemen laba akrual dan manajemen laba riil dengan risiko idiosinkratik. Tata kelola perusahaan diharapkan dapat menurunkan tindakan oportunistik manajer untuk motif-motif tertentu yang diakibatkan adanya informasi asimetri (Sakessia dan Firmansyah, 2020; Firmansyah dan Triastie, 2020; Firmansyah dan Estutik, 2020). Tata kelola perusahaan adalah semua pengaruh yang mempengaruhi proses kelembagaan, termasuk untuk menetapkan pengontrol dan regulator yang terlibat dalam mengatur produksi dan penjualan barang dan jasa (Turnbull, 1997). (Lin dan Hwang, 2010) menemukan terdapat hubungan negatif antara manajemen laba dengan tata kelola perusahaan. Oleh karena itu, adanya tata kelola dapat menurunkan tindakan manajemen laba yang dampaknya dapat menurunkan risiko idiosinkratik perusahaan. Penelitian ini mengukur tata kelola perusahaan dengan menggunakan indeks dari Organization for Economic Cooperation and Development (OECD). Indeks oleh OECD digunakan dalam penelitian yang dilakukan oleh (Cheung et al., 2007), (Cheung et al., 2015), (Saksessia dan Firmansyah, 2020), (Fitania dan Firmansyah, 2020), (Al 'Alam dan Firmansyah, 2019), dan (Firmansyah dan Yusuf, 2020). Sementara itu, beberapa penelitian tata kelola di Indonesia menggunakan komponen-komponenya seperti (Fanani, 2012) yang menggunakan kualitas auditor, komite audit, kepemilikan manajemen, komisaris independen. (Hadiprajitno, 2013) menggunakan struktur kepemilikan dan mekanisme tata kelola untuk mewakili tata kelola perusahaan. Penggunaan indeks OECD dalam penelitian ini bertujuan untuk menilai melihat implementasi tata kelola perusahaan yang lebih komprehensif dan deskriptif di perusahaanperusahaan Indonesia.

Penelitian ini juga menggunakan variabel kontrol yaitu ukuran perusahaan, arus kas operasi, rasio arus kas terhadap harga saham, dan leverage. Penelitian ini juga menggunakan variabel kontrol yaitu ukuran perusahaan, arus kas operasi, rasio arus kas per harga saham, dan leverage. (Kumari et al., 2017), (Zhou et al., 2016), (Chang et al., 2015), dan (Rajgopal dan Venkatachalam, 2011) menemukan bahwa ukuran perusahaan berpengaruh positif terhadap risiko idiosinkratik. Perusahaan yang berukuran besar memiliki risiko internal perusahaan. (Chang et al., 2015) menyimpulkan bahwa arus arus kas operasi berpengaruh positif terhadap risiko idiosinkratik. (Kumari et al., 2017) menemukan rasio arus kas per harga saham berpengaruh positif terhadap risiko idiosinkratik. Selanjutnya, (Rajgopal dan Venkatachalam, 2011), (Zhou et al., 2016), (Chang et al., 2015) menemukan bahwa berpengaruh terhadap risiko idiosinkratik. 


\section{KAJIAN TEORI}

Teori Keagenan. Teori keagenan menjelaskan hubungan yang muncul akibat adanya kontrak antara prinsipal yang melibatkan agen untuk melakukan beberapa tindakan atas nama (Jensen dan Meckling, 1976). Prinsipal terdiri dari pemangku kepentingan yang memberikan dukungan kepada perusahaan, termasuk pemegang saham, kreditur, dan pemerintah (Jensen dan Meckling, 1976). Agen merupakan para pengelola suatu perusahaan yang memiliki kewenangan untuk mengatur dan menjalankan usaha. Fungsi yang berbeda antara prinsipal dan agen menciptakan masalah keagenan. Keadaan ini memungkinkan para manajer untuk memiliki informasi yang lebih baik tentang kondisi perusahaan dibandingkan pemegang saham selaku pemilik perusahaan. (Morris, 1987) menyatakan bahwa teori keagenan secara implisit mengandung informasi asimetri. Prinsipal dan agen selanjutnya bertindak secara kohesif sebagai pemaksimal utilitas. Namun, tidak ada jaminan bahwa agen akan selalu bertindak sesuai dengan kepentingan prinsipal.

Dalam teori keagenan, hubungan antara agen dan prinsipal mengakibatkan ketidakseimbangan informasi (informasi asimetri) karena agen berada pada posisi yang lebih memiliki informasi terkait dengan perusahaan dibandingkan dengan prinsipal. Dalam kondisi demikian, agen dapat menggunakan diskresinya untuk mempengaruhi informasi akuntansi yang disajikan dalam laporan keuangan. Apabila prinsipal menganggap informasi yang dilaporkan oleh agen kepada publik masih memiliki risiko ketidakterbukaan, maka agen akan merespon buruk informasi tersebut yang mengakibatkan adanya penurunan harga saham atau meningkatnya risiko perusahaan. Adanya diskresi manajer dalam penyusunan laporan keuangan mengakibatkan manajer membuat kebijakan akuntansi baik melalui aktivitas akrual maupun melalui aktivitas riil, yang diambil secara sepihak oleh manajer selaku agen dapat mendorong munculnya risiko internal perusahaan. Kebijakan yang dilakukan oleh manajer tidak selalu selaras dengan kepentingan pemegang saham atau kebijakan tersebut dapat dianggap berbahaya dapat mengakibatkan ketidakpastian perusahaan di masa depan.

Pengembangan Hipotesis. Adanya informasi asimetri antara manajer dan pemegang saham, menciptakan ruang bagi manajer untuk memanipulasi informasi keuangan (Chang et al., 2015). Tindakan tersebut dilakukan dengan menggunakan manajemen laba akrual dengan memanfaatkan celah akrual yang diatur dalam standar akuntansi keuangan. Manajemen laba akrual tersebut dilakukan dengan motif yang menguntungkan manajer. (Rajgopal dan Venkatachalam, 2011), (Chen et al., 2012), (Chang et al., 2015), dan (Zhou et al., 2016) menyimpulkan bahwa tindakan manajemen laba akrual dapat meningkatkan risiko idiosinkratik. Risiko internal timbul akibat adanya kebijakan untuk melakukan tindakan manajemen laba akrual yang dilakukan oleh manajer. Oleh karena itu, selain mengakibatkan rendahnya kualitas laba, manajemen laba dapat meningkatkan risiko internal perusahaan.

Manajer memiliki wewenang untuk memilih kebijakan akuntansi dalam melaporkan informasi keuangan. Apapun kebijakan akuntansi yang dipilih manajer, akan mempengaruhi kualitas laba. Standar akuntansi memungkinkan manajer untuk memilih kebijakan dan preferensi akuntansi sendiri, yang akibatnya menciptakan potensi bagi manajer untuk melakukan manipulasi laba oportunistik. Adanya pilihan kebijakan tertentu di dalam standar 
akuntansi keuangan meningkatkan motivasi manajer dalam memilih kebijakan akuntansi tertentu yang lebih mendukung motif tersebut. Padahal tindakan tersebut dapat mendorong risiko internal yang berkontribusi pada total risiko. Dengan demikian, hipotesis pertama penelitian ini adalah:

$\mathbf{H}_{1}$ : Manajemen laba akrual berpengaruh positif terhadap risiko idiosinkratik.

Tindakan manajemen laba akrual mungkin lebih mudah untuk dideteksi oleh auditor atau otoritas pajak (Roychowdury, 2006), sehingga perusahaan hanya menggunakan satu teknik manajemen laba untuk mendapatkan target laba yang diinginkan (Zang, 2006). Dengan memanfaatkan informasi asimetri, manajer cenderung untuk lebih memilih manajemen laba dari aktivitas riil dibandingkan dengan aktivitas berbasis akrual (Graham et al., 2005). Dalam kondisi tersebut, penggunaan manajemen akrual dalam penelitian menjadi tidak valid karena hanya menggunakan aktivitas akrual (Roychowdhury, 2006).

Berbeda dengan manajemen laba akrual, manajemen laba riil merupakan kegiatan yang dilakukan oleh manajer untuk memanipulasi laba melalui operasi rutin. Manajemen laba riil dapat dilakukan melalui tiga operasi yang berbeda yaitu arus kas operasi, biaya produksi, dan biaya diskresioner. Setiap aktivitas riil berpotensi untuk berkontribusi terhadap risiko idiosinkratik, baik secara parsial maupun simultan. (Cohen et al., 2008) menemukan bahwa terjadi pergeseran tren untuk mengalihkan penggunaan manajemen laba akrual sebelum SOX ke penggunaan manajemen laba riil setelah diberlakukannya SOX. Selain itu, (Chang et al., 2015) menemukan bahwa manajemen laba riil berpengaruh positif terhadap risiko idiosinkratik.

Manajer tetap menggunakan berbagai alternatif untuk melakukan manajemen laba ketika aktivitas akrual lebih mudah untuk dapat dideteksi oleh pengguna laporan keuangan, auditor dan otoritas perpajakan. Tindakan manajemen laba riil yang diambil oleh manajer sebagai alternatif dari manajemen laba akrual, tetap memiliki potensi risiko internal perusahaan yang akan merugikan perusahaan di masa mendatang. Tindakan manajemen laba riil yang dilakukan oleh manajer mengakibatkan munculnya dampak yang mengakibatkan respon pasar menjadi menurun. Oleh karena itu, hipotesis kedua dalam penelitian ini adalah:

$\mathbf{H}_{2}$ : Manajemen laba riil berpengaruh positif terhadap risiko idiosinkratik.

Dalam teori keagenan, pemisahan kepentingan antara manajemen mengarah pada perbedaan perilaku oleh para manajer yang tidak selaras dengan (Jensen dan Meckling, 1976). Tata kelola perusahaan pada awalnya dirancang untuk menciptakan lingkungan bisnis yang lebih baik. Hal ini bertujuan untuk mengurangi informasi asimetri antara manajer dan pemegang saham (Firmansyah dan Triastie, 2020) yang dapat mengurangi ruang bagi manajer untuk memanipulasi laba karena manajer akan lebih transparan dalam melaporkan dan mengungkapkan kebijakan yang dibuat kepada pemegang saham. (Firmansyah dan Irawan, 2019) membuktikan salah satu komponen tata kelola yaitu kepemilikan institusional dapat menurunkan tindakan manajemen laba akrual. Menurut (Vo et al., 2016), investor institusional yang merupakan investor aktif dan memiliki peran besar di pasar saham, memiliki peran lebih mendalam di pasar negara berkembang. 
Implementasi tata kelola perusahaan yang baik dapat tindakan oportunistik yang dilakukan oleh manajer (Firmansyah dan Triastie, 2020). Selain itu, tata kelola perusahaan yang baik dapat memaksa manajer untuk dapat meningkatkan kualitas informasi akuntansi yang berguna bagi investor dalam pengambilan keputusan (Firmansyah dan Irawan, 2019). Dengan demikian, penerapan tata kelola perusahaan diharapkan dapat menurunkan perilaku oportunistik manajer dalam pengambilan kebijakan akrual diskresioner terkait dengan penyusunan laporan keuangan. Penerapan tata kelola perusahaan tersebut mendorong manajemen lebih transparan baik dalam pengambilan kebijakan maupun dalam pemberian informasi kepada publik. Kondisi demikian dapat menurunkan risiko internal akibat kebijakan yang tidak selaras dengan kepentingan pemegang saham. Oleh karena itu, hipotesis ketiga dari penelitian ini adalah sebagai berikut:

H3: Tata kelola perusahaan melemahkan hubungan positif antara manajemen laba akrual dan risiko idiosinkratik.

Manajer secara ideal bertindak selaras dengan kepentingan pemegang saham (Firmansyah dan Triastie, 2020). Namun, masalah keagenan dapat mendistorsi hal tersebut dan mendorong manajer mengejar kepentingan pribadinya (Jensen dan Meckling, 1976). Berdasarkan teori keagenan, tata kelola perusahaan merupakan suatu sistem dalam perusahaan yang salah satunya dibentuk untuk menjaga kepentingan dari ketidakselarasan perilaku manajer dengan principal dan informasi asimetris (Firmansyah dan Triastie, 2020). Selain unsur-unsur tata kelola perusahaan seperti komisaris independen, komite audit, kepemilikan manajerial, sebagai alat pengawasan untuk meminimalisasi perilaku manajer yang tidak selaras dengan kepentingan pemegang saham (Firmansyah dan Irawan, 2019), implementasi tata kelola secara komprehensif perlu dilakukan untuk meningkatkan tranparansi informasi perusahaan yang diberikan kepada publik (Firmansyah dan Estutik, 2020).

Adanya alternatif lain dalam melakukan manajemen laba, mengakibatkan manajer tetap mencari celah untuk dapat melukan manajemen laba dengan teknik lainnya seperti manajemen laba riil. Tata kelola perusahaan mempengaruhi keputusan yang dibuat oleh manajer dalam aktivitasnya, termasuk dalam aktivitaas manajemen laba riil. (Prabowo dan Pangestu, 2021) menemukan bahwa komisaris independen dapat menurunkan tindakan manajemen laba riil oleh manajer. Penurunan tindakan manajemen laba riil yang dilakukan oleh manajer dapat menurunkan potensi risiko internal perusahaa.

Tata kelola perusahaan baik sebagai suatu mekanisme pengawasan dan meningkatkan transparansi informasi yang diberikan kepada publik, diharapkan dapat mengurangi tindakan oportunistik manajer. Melalui implementasi tata kelola yang baik, kebijakan manajer yang dapat menimbulkan risiko yang terjadi dapat diminimalisir. Tindakan manajemen laba riil yang lebih sulit untuk dideteksi oleh auditor dan otoritas pajak dibandingkan dengan manajemen laba akrual, merupakan salah bentuk kebijakan yang diambil oleh manajer dapat meningkatkan risiko perusahaan. Oleh karena itu, hipotesis yang keempat adalah:

H4: Tata kelola perusahaan memperlemah hubungan positif antara manajemen laba riil dan risiko idiosinkratik. 


\section{METODE}

Penelitian ini menggunakan pendekatan kuantitatif dengan menggunakan analisis regresi berganda. Penelitian ini menggunakan data sekunder berupa laporan keuangan dan informasi harga saham perusahaan manufaktur yang di Bursa. Data penelitian tersebut diperoleh dari www.idx.co.id, www.idnfinancials.com, dan www.finance.yahoo.com. Tahun 2012 dipilih sebagai awal periode pengamatan karena pada saat itu perusahaanperusahaan di Indonesia mulai menerapkan International Financial Reporting Standards (IFRS). Namun periode yang digunakan dalam penentuan sampel adalah empat tahun yaitu mulai tahun 2014 sampai dengan tahun 2017 karena perhitungan manajemen laba riil membutuhkan data t-2. Dengan demikian, populasinya terdiri dari 136 perusahaan manufaktur yang terdaftar di BEI pada awal tahun 2012. Sampel dalam penelitian ini dengan mengeliminasi beberapa perusahaan dengan menggunakan beberapa kriteria. Berdasarkan, kriteria sampel penelitian ini adalah sebagai berikut:

Tabel 1. Sampel Penelitian

\begin{tabular}{lr}
\hline Kriteria & Jumlah \\
\hline Perusahaan manufaktur di setelah 1 Januari 2012, per 30 Juni 2019 & 136 \\
Perusahaan yang delisted selama periode tahun 2012 sampai dengan 2017 & -8 \\
Perusahaan yang tidak menerbitkan laporan tahunan dalam Bahasa Inggris & -9 \\
Perusahaan yang tidak memberikan informasi dalam laporan tahunan/laporan keuangan & -31 \\
yang dibutuhkan dalam penelitian ini & \\
Perusahaan yang melakukan & -27 \\
Jumlah perusahaan yang dapat digunakan dalam penelitian ini & $\mathbf{6 1}$ \\
Jumlah Tahun & $\mathbf{4}$ \\
Total Sampel & $\mathbf{2 4 4}$ \\
\hline
\end{tabular}

Sumber: data diolah

Penelitian ini menggunakan risiko idiosinkratik sebagai variabel dependen. Dalam mengukur risiko idiosinkratik, penelitian ini menggunakan model tiga faktor Fama dan French (1993) sebagaimana digunakan oleh Firmansyah et al. (2020a) dan Firmansyah et al. (2020b), yaitu sebagai berikut:

$\mathrm{Rt}-\mathrm{Rft}=\beta 0+\beta 1(\mathrm{RMt}-\mathrm{RFt})+\beta 2 \mathrm{SMBt}+\beta 3 \mathrm{HMLt}+\varepsilon$

Dimana:

Rt : tingkat pengembalian saham perusahaan harian

$\mathrm{Rft}$ : tingkat pengembalian bebas risiko dengan menggunakan yield harian dari obligasi pemerintah 10 tahun

RMt : tingkat pengembalian saham pasar agregat harian

SMBt : selisih tingkat pengembalian saham harian ukuran portofolio berdasarkan kapitalisasi pasar

HMLt: selisih tingkat pengembalian saham harian kelompok portofolio berdasarkan kapitalisasi pasar

Distribusi ukuran portofolio (SMB) terdiri dari 50 persen perusahaan besar berdasarkan kapitalisasi pasar, dan 50 persen sisanya dikategorikan sebagai perusahaan 
kecil. Pembagian kelompok portofolio (HML) berdasarkan book to market equity ratio t-1 (HML) terdiri dari 1/3 termasuk perusahaan besar, 1/3 termasuk perusahaan menengah dan $1 / 3$ termasuk perusahaan rendah. Setiap tahun t, perusahaan diberi peringkat dan diurutkan ke dalam portofolio sesuai dengan ukuran kapitalisasi dan rasio book to market equity pada bulan Desember tahun t-1. Tingkat pengembalian dari ukuran portofolio harian (SMB) dihitung sebagai tingkat pengembalian harian portofolio perusahaan besar dikurangi dengan tingkat pengembalian harian portofolio perusahaan kecil. Tingkat pengembalian kelompok portofolio harian (HML) dihitung dengan tingkat pengembalian harian kelompok perusahaan tinggi dikurangi tingkat pengembalian harian kelompok perusahaan rendah. Risiko idiosinkratik dihitung menggunakan standar deviasi dari residual model di atas secara tahunan.

Variabel independen yang diuji dalam penelitian ini adalah manajemen laba akrual dan manajemen laba riil. Proksi manajemen laba akrual dalam penelitian ini mengikuti Rajgopal \& Venkatachalam (2011) dengan model yang dikembangkan oleh (Kothari et al., 2005).

$$
\begin{aligned}
& \text { TAit }=\beta 0+\beta 1\left(\frac{1}{\text { ASSETSit }-1}\right)+\beta 2 \Delta \text { Salesit }+\beta 3 \text { PPEit }+\beta 4 \text { ROAit } \\
& + \text { cit. }
\end{aligned}
$$

Dimana:

$\mathrm{TA}_{\mathrm{it}}$

$\operatorname{ASSETS}_{\mathrm{it}-1}$

$\triangle$ Sales $_{\text {it }}$

$\mathrm{PPE}_{\mathrm{it}}$

$\mathrm{ROA}_{\mathrm{it}}$

cit
: total akrual yang dihitung dengan laba bersih perusahaan i tahun berjalan dikurangi dengan arus kas operasi tahun berjalan, diskalakan dengan total aset tahun $\mathrm{t}-1$.

: total aset perusahaan i tahun tahun $\mathrm{t}-1$

: perubahan penjualan perusahaan i yang diskalakan dengan total aset tahun t-1

: aset tetap perusahaan i yang diskalakan dengan total aset tahun $\mathrm{t}-1$

: tingkat pengembalian terhadap aset perusahaan i tahun t yang dihitung dengan laba rugi tahun tahun i dibagi dengan total tahun $\mathrm{i}$

: residual persamaan

Akrual diskresioner dihitung dengan residual persamaan setiap tahun, untuk selanjutkan dikuadrakatkan (Rajgopal \& Venkatachalam, 2011). Selanjutnya, Manajemen laba riil dalam penelitian ini mengikuti Zang (2012) yaitu penjumlahan dari abnormal overproduction dan abnormal biaya diskresioner. Penelitian ini menggunakan model estimasi untuk biaya produksi normal Roychowdhury (2006). Adapun formula untuk mendapatkan nilai abromal dengan menggunakan persamaan sebagai berikut:

$$
\frac{P R O D}{A t-1}=\alpha 0+\left(\frac{1}{A t-1}\right)+\beta 1\left(\frac{S t}{A t-1}\right)+\beta 2\left(\frac{\Delta S t}{A t-1}\right)+\beta 3\left(\frac{\Delta S t-1}{A t-1}\right)+\varepsilon
$$

\section{Keterangan:}

PROD/At-1 : biaya produksi pada tahun t yang diskala dengan total aktiva pada tahun $\mathrm{t}-1$, dimana PRODt $=$ COGSt $+\Delta \mathrm{INVt}$.

1/At-1 : intersep yang diskala dengan total aktiva pada tahun $\mathrm{t}-1$ dengan tujuan supaya arus kas kegiatan operasi tidak memiliki nilai 0 ketika penjualan dan lag penjualan bernilai 0

St/At-1 : penjualan pada tahun $\mathrm{t}$ yang diskala dengan total aktiva pada tahun $\mathrm{t}-1$.

$\Delta$ St/At-1 $\quad$ : penjualan pada tahun $\mathrm{t}$ dikurangi penjualan pada tahun $\mathrm{t}-1$ yang diskala dengan total aktiva pada tahun $\mathrm{t}-1$ 
$\Delta$ St-1/At-1 : Perubahan penjualan pada tahun $\mathrm{t}-1$ yang diskala dengan total aktiva pada tahun $\mathrm{t}-1$

$\alpha 0 \quad$ : Konstanta

$\varepsilon \quad:$ residual pada tahun $\mathrm{t}$

Apabila hasil residual bernilai positif mengindikasikan bahwa perusahaan melakukan tindakan manajemen laba riil melalui manipulasi biaya produksi. Selanjutnya, manipulasi laba dengan cara menurunkan biaya diskresioner dihitung dengan menggunakan model Roychowdhury (2006) sebagai berikut:

$$
\frac{D I S E X P i}{A t-1}=\alpha 0+\alpha 1\left(\frac{1}{A t-1}\right)+\beta 1\left(\frac{S t}{A t-1}\right) i+\varepsilon
$$

Keterangan:

DISEXP/A : biaya diskresioner didefinisikan sebagai jumlah dari biaya iklan, biaya riset $\mathrm{t}-1$ dan pengembangan (research and development), biaya penjualan, dan biaya administrasi \& umum t yang diskala dengan total aktiva pada tahun t-1

1/At-1 : intersep yang diskala dengan total aktiva pada tahun $\mathrm{t}-1$ dengan tujuan supaya arus kas kegiatan operasi tidak memiliki nilai 0 ketika penjualan dan lag penjualan bernilai 0

St/At-1 : penjualan pada tahun t yang diskala dengan total aktiva pada tahun t-1.

$\alpha 0 \quad$ : Konstanta

$\varepsilon \quad:$ residual pada tahun $\mathrm{t}$

Jika hasil residual bernilai negatif, mengindikasikan bahwa perusahaan melakukan tindakan manajemen laba riil melalui manipulasi, dengan demikian dalam penelitian ini, nilai residual dikalikan dengan -1 . Variabel moderasi yang digunakan untuk menguji hubungan antara variabel dependen dan independen dalam penelitian ini adalah tata kelola perusahaan. Penelitian ini mengikuti perhitungan indeks oleh OECD sebagai proksi tata kelola perusahaan sebagaimana (Cheung et al., 2015). Indeks tersebut mencakup beberapa komponen seperti hak pemegang saham, perlakuan yang adil terhadap pemegang saham, peran pemangku kepentingan, pengungkapan, dan transparansi, dan peran dewan direksi. Proksi ini juga digunakan oleh (Sakessia dan Firmansyah, 2020), (Firmansyah dan Triastie, 2020), (Fitania dan Firmansyah, 2020), (Al 'Alam dan Firmansyah, 2019), (Firmansyah dan Yusuf, 2020). Pengukuran tata kelola dengan menggunkaan indeks ini dilakukan dengan beberapa tahap, seperti menurunkan kelima dimensi utama menjadi beberapa poin yang akan digunakan untuk membentuk indeks tata kelola perusahaan dengan skala 0 s.d. 1. Selanjutnya, kriteria dalam checklist tersebut dicocokkan dengan informasi yang disajikan dalam laporan tahunan perusahaan. Dilakukan dengan mencari kata kunci dalam Bahasa Inggris sesuai dengan kriteria pedoman OECD. Formula tata kelola perusahaan dihitung sebagai berikut:

$$
\text { CGit }=\frac{\text { Total nilai tata kelola perusahaan }}{\text { Jumlah kriteria dalam pedoman tata kelola perusahaan }}
$$

Penelitian ini juga menggunakan variabel kontrol yaitu ukuran perusahaan, arus kas operasi, rasio arus kas per harga saham, dan leverage. Proksi ukuran perusahaan (SIZE) dalam penelitian ini mengikuti (Kumari et al., 2017), (Zhou et al., 2016), (Chang et al., 2015), dan (Rajgopal dan Venkatachalam, 2011) yaitu: 
SIZE $=$ natural logaritma total asset

Arus arus kas operasi (OCF) menggunakan proksi yang digunakan oleh (Chang et al., 2015), yaitu

$$
\mathrm{OCF}=\frac{\text { Total arus kas operasi dalam satu periode }}{\text { Rata-rata total aset dalam periode tersebut }}
$$

Rasio arus kas per harga saham (CFP) menggunakan proksi yang digunakan oleh

Kumari et al. (2017), yaitu:

$$
\mathrm{CFP}=\frac{\text { Jumlah laba sebelum pos luar biasa dan depresiasi }}{\text { Kapitalisasi pasar }}
$$

Leverage (LEV) mengikuti proksi yang digunakan oleh (Rajgopal dan Venkatachalam, 2011), (Zhou et al., 2016), (Chang et al., 2015), yaitu:

$$
\mathrm{LEV}=\frac{\text { Total Utang }}{\text { Total Aset }}
$$

Pengujian hipotesis dalam penelitian ini menggunakan analisis regresi linier berganda dengan data panel. Model 1 menguji pengaruh manajemen laba akrul dan manajemen laba riil terhadap risiko risiko idiosinkratik.

$$
\begin{aligned}
& \text { IVOLit }=\beta \text { it }+\beta \text { 1ABSDAit }+\beta 2 \text { RMit }+\beta 3 \text { SIZEit }+\beta 40 C F i t+\beta 5 \text { LEVit } \\
& +\beta 6 \text { CFPit }+ \text { eit }
\end{aligned}
$$

Model 2 menguji peran tata kelola perusahaan dalam hubungan antara antara variabel independen yaitu manajemen laba akrual dan manajeman laba riil dan variabel dependen yaitu risiko idiosinkratik.

$$
\begin{aligned}
& \text { IVOLit }=\beta 0 i t+\beta 1 \text { ABSDAit }+\beta 2 \text { RMit }+\beta 3 \text { CGit }+\beta 4 \text { ABSDAit } * \text { CGit } \\
& +\beta 5 \text { RMit } * \text { CGit }+\beta 6 \text { SIZEit }+\beta 7 \text { OCFit }+\beta 8 \text { LEVit }+\beta 9 \text { CFPit } \\
& + \text { eit }
\end{aligned}
$$

Dimana:

IVOL : risiko idiosinkratik perusahaan i periode $\mathrm{t}$

ABSDA : manajemen laba akrual perusahaan i periode $\mathrm{t}$

RM : manajemen laba akrual perusahaan i periode $\mathrm{t}$

CG : tata kelola perusahaan perusahaan i periode $\mathrm{t}$

SIZE : ukuran perusahaan perusahaan i periode $\mathrm{t}$

OCF $\quad:$ arus kas operasi perusahaan i periode $\mathrm{t}$

LEV : leverage perusahaan i periode $\mathrm{t}$

CFP : rasio arus kas terhadap harga saham perusahaan i periode $\mathrm{t}$ 


\section{HASIL}

Statistik deskriptif variabel dalam penelitian ini adalah sebagai berikut:

Tabel 2. Statistik deskriptif

\begin{tabular}{crrrrrr}
\hline Variable & \multicolumn{1}{c}{ Mean } & \multicolumn{1}{c}{ Med } & \multicolumn{1}{c}{ Min. } & \multicolumn{1}{c}{ Max. } & Std. Dev. & N \\
\hline IVOL & 0.097 & 0.073 & 0.002 & 0.901 & 0.090 & 244 \\
ABSDA & 0.006 & 0.001 & $4.74 \mathrm{E}-10$ & 0.308 & 0.022 & 244 \\
RM 1 & $-1.5 \mathrm{E}-15$ & 0.067 & -2.985 & 1.550 & 0.386 & 244 \\
CG & 0.570 & 0.582 & 0.220 & 0.805 & 0.0973 & 244 \\
SIZE & 28.919 & 28.769 & 24.076 & 33.320 & 1.629 & 244 \\
OCF & 0.069 & 0.057 & -0.218 & 0.467 & 0.084 & 244 \\
LEV & 0.579 & 0.490 & 0.073 & 5.073 & 0.634 & 244 \\
ROA & 0.032 & 0.023 & -1.279 & 0.479 & 0.117 & 244 \\
CFP & 0.750 & 0.104 & -7.318 & 131.039 & 8.408 & 244 \\
\hline
\end{tabular}

Sumber: data diolah

Selanjutnya, hasil uji pemilihan model regresi (uji Chow, uji Lagrange Multiplier, uji Hausman) menunjukkan bahwa pengujian hipotesis untuk model 1 dan model 2 yang paling sesuai adalah random effect model (REM). Adapun ringkasan hasil pengujian tersebut sebagai berikut:

Table 3. Ringkasan Hasil Uji Hipotesis

\begin{tabular}{lrrrrrrrr}
\hline & Coeff & t-Stat & Prob & & Coeff & t-Stat & Prob & \\
\hline ABSDA & 0.430 & 1.75 & 0.040 & $* *$ & -0.795 & -0.34 & 0.368 & \\
RM1 & 0.073 & 3.73 & 0.000 & $* * *$ & -0.040 & -0.35 & 0.363 & \\
CG & & & & & 0.159 & 2.10 & 0.018 & $* *$ \\
RM1*CG & & & & & 0.191 & 0.97 & 0.166 & \\
ABSDA*CG & & & & & 2.505 & 0.53 & 0.298 & \\
SIZE & -0.005 & -1.30 & 0.096 & $*$ & -0.007 & -1.69 & 0.045 & $* *$ \\
OCF & -0.023 & -0.31 & 0.376 & & -0.036 & -0.48 & 0.317 & \\
LEV & 0.006 & 0.51 & 0.305 & & 0.0156 & 1.28 & 0.099 & $*$ \\
CFP & 0.001 & 1.93 & 0.026 & $* *$ & 0.001 & 1.11 & 0.134 & \\
Adj R2 & 0.110 & & & & 0.128 & & & \\
F-Stat & 23.190 & & & & 28.5 & & & \\
Prob (F-Stat) & 0.000 & & & & 0.000 & & & \\
\hline
\end{tabular}

Sumber: data diolah

\section{PEMBAHASAN}

Hubungan Manajemen Laba Akrual dan Risiko Idiosinkratik. Hasil pengujian hipotesis menunjukkan bahwa manajemen laba akrual berpengaruh positif terhadap risiko idiosinkratik. Temuan ini mendukung penelitian (Rajgopal dan Venkatachalam, 2011), (Chang et al., 2015), (Zhou et al., 2016). Penelitian ini menunjukkan bahwa manajemen laba 
dapat membahayakan kelangsungan dan kelangsungan hidup perusahaan. Kualitas laba yang dapat dilihat dari kualitas akrual menjadi salah satu faktor penting bagi investor untuk mengambil keputusan dapat dilihat dari kualitas akrual. Tindakan manajemen laba akrual mendorong tingkat risiko idiosinkratik yang tinggi. Manajemen laba akrual dapat dilakukan dengan memanfaatkan akrual yang lancar maupun akrual yang tidak lancar. Manajer memiliki keleluasaan yang paling besar atas akrual saat ini seperti pengakuan pendapatan lebih awal dan penurunan utang usaha (Jaggi et al., 2009). Manajer tidak hanya memfokuskan pada akrual diskresioner lancar saja dalam melakukan manajemen laba akrual, tetapi manajer juga menggunakan akrual diskresioner tidak lancar seperti depresiasi dan amortisasi.

Manajemen laba yang dilakukan oleh manajer menggunakan akrual diskresioner mendorong munculnya risiko idiosinkratik. Para manajer melakukan manajemen laba akrual sebagai manifestasi dari prestasi oportunistik. (Scott, 2015) menyatakan bahwa manajemen laba dapat dianggap sebagai aktivitas oportunistik. Ada beberapa cara untuk melakukan manajemen laba berbasis akrual melalui preferensi metode akuntansi. Beberapa metode untuk memanipulasi akrual diskresioner adalah dengan meningkatkan atau mengurangi beban amortisasi, mengakui pendapatan lebih awal, mengurangi utang usaha, dan meningkatkan persediaan. Praktik manajemen laba yang agresif dapat menyebabkan pengambilan keputusan yang tidak akurat karena kualitas laba yang disajikan dalam laporan keuangan sangat buruk. Aktivitas manajemen laba yang oportunistik ini berpotensi menurunkan kepercayaan investor terhadap informasi keuangan yang diberikan oleh perusahaan, yang berujung pada pengabaian informasi keuangan.

Penerapan IFRS yang dimulai sejak tahun 2012 seyogyanya mampu menciptakan lingkungan bisnis yang lebih baik dan mengarah pada pengambilan keputusan yang lebih baik oleh para manajer. Kondisi tersebut tidak menurunkan manajer untuk tetap melakukan aktivitas manajemen laba (Firmansyah dan Irawan, 2018). Risiko idiosinkratik yang semakin meningkat mengakibatkan perusahaan dalam keadaan berbahaya di masa mendatang. Namun, apabila manajer dapat menekan atau menghindari aktivitas oportunistik melalui manajemen laba akrual, risiko idiosinkratik perusahaan dapat diminimalkan.

Aktivitas manajemen laba akrual di Indonesia yang relatif tinggi dilakukan oleh manajemen disebabkan oleh beberapa faktor seperti lemahnya penegakan hukum, kurangnya perlindungan investor, dan tingginya konsentrasi kepemilikan perusahaan (Edriyani, 2017). Selain itu, bahwa manajemen laba akrual dilakukan oleh manajer untuk menghindari pajak dalam menanggapi penurunan tarif di Indonesia (Wijaya dan Martani, 2011; Surachman dan Firmansyah, 2017; Pajriansyah dan Firmansyah, 2018; Kusuma dan Firmansyah, 2018; Falbo dan Firmansyah, 2021). Lingkungan bisnis yang tidak kondusif dan motif lain untuk melakukan manajemen laba menjadi faktor utama tingginya tindakan manajemen laba di Indonesia. Kondisi ini menyebabkan semakin tingginya porsi risiko idiosinkratik dari total risiko perusahaan di pasar. Selain itu, tingginya risiko idiosinkratik dapat menurunkan respon investor di pasar modal (Firmansyah et al., 2020a).

Hubungan Manajemen Laba Riil dan Risiko Idiosinkratik. Berdasarkan hasil pengujian hipotesis, manajemen laba riil berpengaruh positif terhadap risiko idiosinkratik. Temuan ini sejalan dengan (Chang et al., 2015). Hasil pengujian ini menunjukkan bahwa terdapat tren pergeseran dari manajemen laba akrual ke manajemen laba riil, meskipun besarnya masih 
rendah. Temuan ini berbeda dengan (Firmansyah dan Irawan, 2018) yang menyimpulkan tidak terdapat pergeseran dari manajemen laba akrual menjadi manajemen laba riil. Manajemen laba riil dapat dilakukan dengan melaporkan harga pokok penjualan yang lebih rendah melalui peningkatan produksi (Gunny, 2005). Overproduction dapat menyembunyikan dan menyamarkan biaya tetap overhead tetap atas sejumlah besar persediaan, yang menyebabkan biaya tetap per unit yang lebih rendah. Pengurangan biaya tetap yang tidak diimbangi dengan kenaikan biaya marjinal per unit mengakibatkan biaya total per unit menurun. Penurunan beban pokok penjualan yang dilaporkan akan menyebabkan laba bersih yang lebih tinggi. Selain itu, manajemen laba riil dapat dilakukan dengan menurunkan biaya diskresioner seperti biaya iklan, biaya penelitian dan pengembangan, dan biaya penjualan dan administrasi. Pengurangan biaya tersebut akan meningkatkan pendapatan pada periode berjalan.

Menurut (Geraldina, 2013), manajemen laba riil dan manajemen laba akrual dapat saling menggantikan atau melengkapi. Hal ini dapat ditunjukkan dengan koefisien manajemen laba riil dan manajemen laba akrual. Apabila kedua proksi signifikan dan memiliki arah yang sama terhadap risiko idiosinkratik, keduanya saling melengkapi. Berdasarkan hasil pengujian dalam penelitian, menunjukkan bahwa terkait dengan timbulnya risiko idiosinkratik, manajer melakukan manajemen laba riil dan akrual secara bersamaan untuk memanipulasi laba. Kombinasi kedua aktivitas manajemen laba tersebut meningkatkan risiko idiosinkratik yang berpotensi mengancam keberlangsungan perusahaan di masa mendatang.

\section{Peran Tata Kelola Perusahaan dalam Memperlemah Hubungan Positif Manajemen} Laba Akrual dan Risiko Idiosinkratik. Hasil pengujian hipotesis dalam penelitian ini menunjukkan bahwa tata kelola perusahaan tidak dapat memperlemah hubungan positif manajemen laba akrual dan risiko idiosinkratik. Temuan ini mendukung temuan (Yanuar dan Restuti, 2015) dan (Istianingsih, 2016) bahwa tata kelola perusahaan tidak dapat menurunkan tindakan manajemen laba akrual. Hal ini menunjukkan praktik tata kelola perusahaan yang tidak efektif. Selain itu, implementasi tata kelola perusahaan di Indonesia hanya terfokus pada pemenuhan persyaratan administrasi (Saksessia \& Firmansyah, 2020; Firmansyah \& Estutitk; Yanuar \& Restuti, 2015).

(Scott, 2015) menyatakan bahwa apabila manajer melakukan manajemen laba untuk meningkatkan jumlah laba dari yang seharusnya dalam suatu periode, maka periode berikutnya akan memaksa laba masa depan menjadi turun sama seperti laba saat ini yang dinaikkan. Peningkatan manajemen laba akrual bertujuan juga apabila manajer menghendaki adanya penundaan kerugian di tahun berjalan. Akibatnya, manajer dapat menutupi berkinerja buruk perusahaan dengan manajemen laba akrual. Oleh karena itu, manajemen laba akrual yang menurunkan kualitas laporan keuangan dapat menyesatkan pengambilan keputusan. Terkait dengan hal tersebut, akuntan dan auditor berperan untuk menemukan garis tipis antara manajemen laba dan perhitungan laba yang salah. Scott (2015) menambahkan bahwa garis tipis ini seharusnya ditentukan oleh tata kelola perusahaan yang efektif, yang diperkuat oleh badan pengawas pasar modal, pasar tenaga kerja manajerial, badan penyusun standar, dan komisi sekuritas. Namun, hasil pengujian ini menunjukkan bahwa implementasi tata kelola tidak berhasil memiliki peran tersebut. 
(Wibowo, 2012) mengungkapkan bahwa penerapan tata kelola di Indonesia hanya bersifat kosmetik dan bertujuan untuk menciptakan citra yang lebih baik di masyarakat. Menurut (Wibowo, 2012), dari semua survei yang dilakukan terkait dengan tata kelola perusahaan, Indonesia selalu berada di urutan terbawah dari semua negara terpilih. Hasil tersebut sejalan dengan Asian Corporate Governance Association (ACGA), yang menunjukkan bahwa penerapan tata kelola perusahaan tidak membaik secara signifikan dari waktu ke waktu (CLSA Limited, 2018). (Wibowo, 2012) menambahkan beberapa faktor penyebab belum efektifnya penerapan tata kelola di Indonesia dapat diklasifikasikan menjadi tiga kelompok, yaitu penggerak internal, penggerak eksternal, dan penggerak struktur kepemilikan. Pertama, faktor pendorong internal antara lain kurangnya komitmen pejabat dan karyawan, pemahaman yang buruk tentang prinsip-prinsip tata kelola perusahaan, tidak adanya panutan yang baik, ketidaksesuaian budaya perusahaan yang mendukung tata kelola perusahaan yang baik, dan pengendalian internal yang tidak efektif (Djatmiko, 2004). Kedua, penggerak eksternal dengan melibatkan regulasi, penegakan hukum, dan peran lembaga terkait seperti Bank Sentral, Kementerian Keuangan, Otoritas Jasa Keuangan, dan Komite Nasional Kebijakan Tata Kelola Perusahaan. Semua lembaga harus menyelaraskan peran dan kewenangannya dengan pengaturan dan mengawasi penerapan tata kelola perusahaan di perusahaan-perusahaan Indonesia. Terakhir, struktur kepemilikan mempengaruhi penerapan tata kelola perusahaan jika kepemilikan terkonsentrasi pada beberapa pihak. Kepemilikan terkonsentrasi terjadi jika individu atau pihak memiliki 40 persen saham perusahaan. Kepemilikan yang terkonsentrasi dapat membawa dampak negatif bagi perusahaan karena wewenang dan kekuasaan yang melekat padanya, sehingga menimbulkan ketidakadilan di antara para pemegang saham.

Hasil penelitian ini juga menunjukkan bahwa tata kelola perusahaan tidak berhasil dalam menurunkan risiko idiosinkratik. Penerapan tata kelola perusahaan di Indonesia tetap memberi ruang untuk meningkatkan risiko melalui kebijakan akrual diskresioner yang dijalankan manajer. Kondisi ini dapat menunjukkan beberapa hal, seperti belum optimalnya penerapan tata kelola perusahaan di Indonesia dan penerapan tata kelola perusahaan yang hanya berfokus pada kepatuhan terhadap peraturan dan persyaratan administratif. Penerapan tata kelola perusahaan yang baik tidak menjamin perusahaan memiliki risiko idiosinkratik yang rendah.

\section{Peran Tata Kelola Perusahaan dalam Memperlemah Hubungan Positif Antara} Manajemen Laba Riil dan Risiko Idiosinkratik. Hasil pengujian hipotesis dalam penelitian ini menunjukkan bahwa tata kelola perusahaan tidak dapat memperlemah hubungan positif antara manajemen laba riil dan risiko idiosinkratik. Temuan ini juga menegaskan bahwa praktik manajemen laba riil lebih sulit untuk diidentifikasi. Pertimbangan manajer dalam melakukan manajemen laba riil antara lain lingkungan bisnis, proses bisnis, pemangku kepentingan, likuiditas perusahaan, dan kapasitas produksi. Dalam kompleksitas bisnis yang dijalankan oleh perusahaan, tidak mudah untuk menerapkan tata kelola perusahaan dalam aktivitas riil. Penerapan tata kelola perusahaan yang baik perlu ditunjang oleh komitmen yang kuat semua pihak.

Laporan yang dikeluarkan oleh Asian Corporate Governance Association (ACGA) menempatkan Indonesia sebagai peringkat terendah dalam penerapan tata kelola perusahaan di antara negara-negara yang disurvei di Indonesia (CLSA Limited, 2018). Laporan tersebut 
juga menyatakan bahwa reformasi tata kelola perusahaan di Indonesia masih rendah dalam prioritas pemerintah. Hasil tersebut bahwa penerapan tata kelola perusahaan di Indonesia masih belum efektif dan efisien. Namun, berdasarkan informasi ini masih sulit untuk mengidentifikasi faktor mana yang paling berkontribusi dalam pengujian dalam penelitian ini karena proksi tata kelola dalam penelitian ini menggunakan indeks tata kelola perusahaan yang komprehensif dari OECD. (Wibowo, 2012) menyatakan bahwa tata kelola perusahaan di Indonesia sebagian besar bertujuan untuk menciptakan citra yang baik bagi publik, implementasinya selama ini tidak konsisten. Komitmen yang lebih kuat dari beberapa pihak dari internal maupun eksternal perusahaan untuk menciptakan tata kelola perusahaan yang lebih berdampak dan bermanfaat.

\section{KESIMPULAN}

Penelitian ini menemukan bahwa manajemen laba akrual dan manajemen laba riil mendorong timbulnya risiko idiosinkratik. Manajemen laba merupakan yang dilakukan dengan memanfaatkan diskresi melalui kebijakan akrual dan aktivitas riil mendorong risiko internal perusahaan. Tata kelola perusahaan gagal melemahkan hubungan antara manajemen laba akrual dan risiko idiosinkratik, serta hubungan manajemen laba riil dan risiko idiosinkratik. Penerapan tata kelola di perusahaan manufaktur Indonesia belum mampu menurunkan risiko internal perusahaan yang diakibatkan oleh aktivitas manajemen laba baik secara akrual maupun riil yang dilakukan oleh manajer. Kondisi ini menunjukkan bahwa tata kelola perusahaan belum diterapkan secara efektif. Selain itu, terdapat indikasi bahwa penerapan tata kelola perusahaan di Indonesia hanya untuk memenuhi persyaratan administrasi dan regulasi.

Keterbatasan penelitian ini adalah data yang digunakan hanya menggunakan data perusahaan-perusahaan dalam sektor manufaktur di Indonesia, sehingga hasil pengujian dalam penelitian ini tidak menggambarkan kondisi seluruh perusahaan di Indonesia. Selain itu, dari data yang digunakan dalam penelitian masih terbatas. Penelitian selanjutnya dapat menggunakan sampel perusahaan sektor lainnya atau sektor yang lebih luas yang lebih panjang untuk mendapatkan hasil pengujian yang lebih baik. Penelitian selanjutnya juga dapat menggunakan pengukuran tata kelola perusahaan lainnya seperti dengan menggunakan indeks tata kelola, maupun komponen-komponen tata kelola seperti komisaris independen, komite audit, dan kepemilikan saham institusi. Penelitian ini mengindikasikan kepada Otoritas Jasa Keuangan (OJK) untuk meningkatkan kebijakan terkait dengan tata kelola perusahaan dan monitoring penerapan tata kelola perusahaan oleh perusahaan listed di Bursa Efek Indonesia. Selain itu, OJK perlu berkoordinasi dengan Ikatan Akuntan Indonesia terkait untuk menurunkan tindakan manajemen laba yang dilakukan perusahaan. Hasil penelitian ini juga dapat digunakan oleh investor dan calon investor sebagai tambahan dalam melakukan analisis dalam pengambilan keputusan investasi di pasar modal Indonesia. 


\section{DAFTAR PUSTAKA}

Al 'Alam, M. P. A., and Firmansyah, A. (2019). The effect of financial reporting quality, debt maturity, political connection, and corporate governance on investment efficiency: evidence from Indonesia. International Journal of Innovation, Creativity and Change, 7 (6), 39-56

Anggiyanti, L. D. (2018). Pengaruh idiosyncratic risk dan likuiditas saham terhadap return saham perusahaan manufaktur yang terdaftar di Bursa Efek Indonesia (BEI). Jurnal Manajemen Bisnis Indonesia, 7(4), 390-399.

Anwar, S., Singh, S., and Jain, P. K. (2015). Cash dividend announcements and stock return volatility: evidence from India. Procedia Economics and Finance, 30, 38-49. https://doi.org/10.1016/S2212-567 (15) 01253-8.

Aziz, T., and Ansari, V. A. (2017) Idiosyncratic volatility and stock returns: Indian evidence. Cogent Economics \& Finance, 5(1), 1-20. https://doi.org/10.1080/23322039.2017.1420998.

Bozhkov, S., Lee, H., Sivarajah, U., Despoudi, S., and Nandy, M. (2018). Idiosyncratic risk and the crosssection of stock returns: the role of mean-reverting idiosyncratic volatility. Annals of Operations Research, 1-34. https://doi.org/10.1007/s10479-0182846-7.

Bowman, E. H. (1980). A risk/return paradox for strategic management.

Cahyati, A. D. (2011). Peluang Manajemen Laba Pasca Konvergensi Ifrs: Sebuah Tinjauan Teoritis Dan Empiris. Jurnal F. Ekonomi : JRAK, 2(01), 1-7.

Chang, S. H., Wang, T. S., Chiu, A. A., and Huang, S. Y. (2015). Earnings management and idiosyncratic risk-evidence from the post-Sarbanes-Oxley Act period. Investment Management and Financial Innovations, 12(2), 117-126.

Chen, C., Huang, A. G., and Jha, R. (2012). Idiosyncratic return volatility and the information quality underlying managerial discretion. Journal of Financial and Quantitative Analysis, 47(04), 873-899. http://doi.org/10.1017/s002210901200018x.

Chen, H., Lin, C., Kao, T., and Wei, T. (2016). The Effects of Corporate Governance on Idiosyncratic Risk: Evidence from Financial Institutions in Taiwan, 4(2), 17-24. https://doi.org/10.15640/jfbm.v4n2a3.

Cheung, Y. L., Thomas Connelly, J., Limpaphayom, P., and Zhou, L. (2007). Do investors really value corporate governance? Evidence from the Hong Kong market. Journal of International Financial Management \& Accounting, 18(2), 86-122.

Cheung, Y. L., J. Thomas Connelly, Jesus P. Estabislao, Piman L., Tong Lu, and Sidharta Utama (2015). Corporate Governance and Firm Valuation in Asian Emerging Markets. Corporate Governance in Emerging Markets: Theories, Practices and Cases: 27-53.

Chichernea, D. C., Petkevich, A., and Zykaj, B. B. (2013). Idiosyncratic volatility, institutional ownership, and investment horizon. European Financial Management, 21(4), 613-645. http://doi.org/10.1111/j.1468-036X.2013.12033.x.

Chowdury, S. S. H., and Hossain, M. (2019). Is idiosyncratic volatility priced in Bangladesh stock market? International Journal of Economics and Management, 13(2), 305-317.

Cohen, D. A., Dey, A., and Lys, T. Z. (2008). Real and accrual-based earnings management in the pre-and post-Sarbanes-Oxley periods. The accounting review, 83(3), 757-787. 
CSLA Limited (2018, 5 Desember). CG Watch 2018: Hard decisions. https://www.clsa.com/wp-content/uploads/2018/12/CG-Watch-2018-Short-version181205-L.pdf.

Darmawan, J. F., Murhadi, W. R., and Mahadwartha, P. A. (2017). The influence of idiosyncratic volatility, market risk, and size on stock return of a non-financial company registered in Indonesia Stock Exchange in the period of 2012 - 2016. Journal of Management and Business, 16(1), 12-18. https://doi.org/10.24123/jmb.v16i1.277.

DeFond, M., Hu, X., Hung, M., and Li, S. (2011). The impact of mandatory IFRS adoption on foreign mutual fund ownership: The role of comparability. Journal of accounting and economics, 51(3), 240-258.

Djatmiko, H.E. (2004). Ada Kemajuan, Banyak Keprihatinan, SWA, XX, 4.

Edriyani, N. A. (2017). Analisis Perbandingan Praktik Manajemen Laba pada Perusahaan Syariah di Indonesia dan Malaysia: Studi pada Perusahaan Manufaktur Syariah yang Terdaftar dalam Bursa Efek Indonesia dan Bursa Malaysia Berhad. Skripsi: Fakultas Ekonomi dan Bisnis, Universitas Gadjah Mada.

Falbo, T. D., dan Firmansyah, A. (2021). Penghindaran pajak di Indonesia: multinationality dan manajemen laba. Bisnis-Net Jurnal Ekonomi dan Bisnis, 4(1), 94-110.

Fama, E. F., and French, K. R. (1993). Common risk factors in the returns on stocks and bonds. Journal of financial economics, 33(1), 3-56.

Fanani, Z. (2014). Karakteristik Perusahaan dan Corporate Governance terhadap Manajemen Laba: Studi Analisis Meta. Jurnal Keuangan dan perbankan, 18(2), 181200.

Fazil, G., and İpek, A. (2013). Does Idiosyncratic Volatility Matter in the Emerging Markets? Istanbul Stock Exchange Evidence. Economic Research-Ekonomska Istraživanja, 26(3), 133-150.

Firmansyah, A., dan Irawan, F. (2018). Adopsi IFRS, manajemen laba akrual dan manajemen laba riil. ASSETS: Jurnal Akuntansi dan Pendidikan, 7(2), 81-94.

Firmansyah, A., and Irawan, F. (2019). Do IFRS adoption and corporate governance increase accounting information quality in Indonesia? Accounting Analysis Journal, $8(1), 59-65$.

Firmansyah, A., and Yusuf, Y. (2020). The value relevance of corporate disclosures: social responsibility, intellectual capital, corporate governance. ASSETS: Jurnal Akuntansi dan Pendidikan, 9(1), 61-71.

Firmansyah, A., and Triastie, G. A. (2020). The role of corporate governance in emerging market: Tax avoidance, corporate social responsibility disclosures, risk disclosures, and investment efficiency. Journal of Governance and Regulation, 9(3), 8-26

Firmansyah, A., and Estutik, R. S. (2020). Environmental responsibility performance, corporate social responsibility disclosure, tax aggressiveness: does corporate governance have a role? Journal of Governance and Regulation, 9(4), 8-24.

Firmansyah, A., Utami, W., Umar, H., and Mulyani, S. D. (2020). The role of derivative instruments on risk relevance from emerging market non-financial companies. Journal of Governance and Regulation, 9(2), 45-63.

Firmansyah, A., Sihombing, P., and Kusumastuti, S. R. (2020b). The determinants of idiosyncratic volatility in Indonesia banking industries. Jurnal Keuangan dan 
Perbankan, 24(2), 175-188.

Fitania, D. N., and Firmansyah, A. (2020). The effect of geographic diversification, competition level, and corporate governance on risk disclosure. International Journal of Scientific \& Technology Research, 9(3), 366-372

Geraldina, I. (2013). Preferensi Manajemen Laba Akrual atau Manajemen Laba Riil dalam Aktivitas Tax Shelter. Jurnal Akuntansi dan Keuangan Indonesia, 10(2), 206-224.

Godfrey, J., Hodgson, A., Tarca, A., Hamilton, J., \& Holmes, S. (2010). Accounting theory.

Gunny, K. (2005). What are the consequences of real earnings management? Working Paper, University of Colorado.

Hadiprajitno, P. B. (2013). Struktur kepemilikan, mekanisme tata kelola perusahaan, dan biaya keagenan di Indonesia (studi empirik pada perusahaan di Bursa Efek Indonesia). Jurnal akuntansi dan auditing, 9(2), 97-127.

Jaggi, B., Leung, S., and Gul, F. (2009). Family control, board independence and earnings management: Evidence based on Hong Kong firms. Journal of Accounting and Public Policy, 28(4), 281-300.

Jammernegg, W., and Kischka, P. (2007). Risk-averse and risk-taking newsvendors: a conditional expected value approach. Review of Managerial Science, 1(1), 93-110.

Jensen, M. C., and Meckling, W. H. (1976). Theory of the firm: Managerial behavior, agency costs and ownership structure. Journal of financial economics, 3(4), 305-360.

Kothari, S. P., Leone, A. J., and Wasley, C. E. (2005). Performance matched discretionary accrual measures. Journal of accounting and economics, 39(1), 163-197.

Kumari, J., Mahakud, J., and Hiremath, G. S. (2017). Determinants of idiosyncratic volatility: Evidence from the Indian stock market. Research in International Business and Finance, 41, 172-184.

Kusuma, C. A., dan Firmansyah, A. (2018). Manajemen Laba, Corporate Governance, Kualitas Auditor Eksternal Dan Agresivitas Pajak. Jurnal Telaah Akuntansi dan Bisnis, 8(1), 108-123.

Li, X., Hou, K., and Zhang, C. (2019). Intangible factor and idiosyncratic volatility puzzles. Finance Research Letters, 1-30. https://doi.org/10.1016/j.frl.2019.101403.

Lin, J. W., and Hwang, M. I. (2010). Audit quality, corporate governance, and earnings management: A meta-analysis. International Journal of Auditing, 14(1), 57-77.

Liu, B., and Di Iorio, A. (2012). Idiosyncratic volatility on Australian stock returns. Working paper. RMIT University.

Liu, B., Di lorio, A., and De Silva, A. (2014). Do stock fundamentals explain idiosyncratic volatility? Evidence for Australian stock market. 23rd Annual Meeting of the European Financial Management Association. European Financial Management Association

Morris, R. D. (1987). Signalling, agency theory and accounting policy choice. Accounting and business Research, 18(69), 47-56.

Narendra, A., dan Haryanto, H. (2013). Pengaruh pengadopsian international financial reporting standard (ifrs) terhadap manajemen laba (studi empiris pada perusahaan manufaktur yang terdaftar di Bursa Efek Indonesia pada tahun 2011-2012). Diponegoro Journal of Accounting, 2(4), 270-279.

Noviayanti, P., and Husodo, Z. (2018). Exposure to common idiosyncratic volatility on stock returns in ASEAN stock markets. International Journal of Business and Society, 
19, 499-516.

Pajriyansyah, R., dan Firmansyah. A. (2018). Pengaruh leverage, kompensasi rugi fiskal dan manajemen laba terhadap penghindaran pajak. Keberlanjutan, 2(1), 431-459.

Prabowo, A., dan Pangestu, I. S. (2021). Leverage, tata kelola perusahaan, dan manajemen laba riil. Organum: Jurnal Saintifik Manajemen dan Akuntansi, 4(1), 72-89. https://doi.org/10.35138/organum.v4i1.133.

Pujianto, M., dan Wibowo, B. (2019). Uji empiris pengaruh idiosyncratic volatility terhadap expected return: aplikasi Fama-French five factor model. MIX: Jurnal Ilmiah Manajemen, 9(2), 268-281.

Qadan, M., Kliger, D., and Chen, N. (2019). Idiosyncratic volatility, the VIX, and stock returns. The North American Journal of Economics and Finance, 47, 431-441. https://doi.org/10.1016/j.najef.2018.06.003.

Rajgopal, S., and Venkatachalam, M. (2011). Financial reporting quality and idiosyncratic return volatility. Journal of Accounting and Economics, 51(1-2), 1-20.

Roychowdhury, S. (2006). Earnings management through real activities manipulation. Journal of accounting and economics, 42(3), 335-370.

Saksessia, D., Firmansyah, A. (2020). The role of corporate governance on earnings quality from positive accounting theory framework. International Journal of Scientific \& Technology Research 9 (1), 808-820

Scott, W. R. (2015). Financial Accounting Theory Seventh Edition. United States: Canada Cataloguing.

Septyanto, D. (2013). Faktor-faktor yang mempengaruhi investor individu dalam pengambilan keputusan investasi sekuritas di Bursa Efek Indonesia (BEI). Jurnal Ekonomi Universitas Esa Unggul, 4(2), 90-101.

Surahman, A., and Firmansyah, A. (2020). Pengaruh manajemen laba melalui penyimpangan akuntansi, aktivitas laba riil dan akrual terhadap agresivitas pajak. Fundamental Management Journal, 2 (2), 10-28.

Tan, M., and Liu, B. (2016). CEO's Managerial Power, Board Committee Memberships And Idiosyncratic Volatility. International Review of Financial Analysis, 48, 21-30. http://doi.org/10.1016/j.irfa.2016.09.003.

Titman, S., Keown, A. J., Martin, J. D., and Martin, T. (2011). Financial management: Principles and applications (Vol. 11). Boston: Prentice Hall.

Tzouvanas, P., Kizys, R., Chatziantoniou, I., and Sagitova, R. (2020). Environmental disclosure and idiosyncratic risk in the European manufacturing sector. Energy Economics, 87, 1-13. https://doi.org/10.1016/j.eneco.2020.104715.

Turnbull, S. (1997). Corporate governance: its scope, concerns and theories. Corporate Governance: An International Review, 5(4), 180-205.

Vo, X. V. (2016). Does institutional ownership increase stock return volatility? Evidence from Vietnam. International Review of Financial Analysis, 45, 54-61. https://doi.org/10.1016/j.irfa.2016.02.006.

Vo, X. V., Vo, V. P., and Nguyen, T. P. (2020) Abnormal returns and idiosyncratic volatility puzzle: An empirical investigation in Vietnam stock market. Cogent Economics \& Finance, 8(1), 1-25. https://doi.org/10.1080/23322039.2020.1735196.

Wang, M. S. (2013). Idiosyncratic volatility and the expected stock returns for exploring the relationship with panel threshold regression. Asia-Pacific Finance Markets, 20(2), 
113-129. https://doi.org/10.1007/s10690-012-9161-0.

Wibowo, E. (2012). Implementasi Good Corporate Governance Di Indonesia. Jurnal ekonomi dan Kewirausahaan, 10(2).

Wijaya, M., dan Martani, D. (2011). Praktik Manajemen Laba Perusahaan Dalam Menanggapi Penurunan Tarif Pajak Sesuai UU No. 36 Tahun 2008. Dalam Simposium Nasional XIV Aceh.

Yanuar A.D. and Restuti. M.M.D. (2015). Pengaruh Corporate Governance Terhadap Manajemen Laba di Industri Perbankan Indonesia. The $8^{\text {th }}$ NCFB and Doctoral Colloquium Towards a New Indonesia Business Architecture Sub Tema:"Crisis Management: Key to Sustainable Business Development"(209-222). Fakultas Bisnis dan Pascasarjana UKWMS.

Zang, A. Y. (2012). Evidence on the trade-off between real activities manipulation and accrual-based earnings management. The Accounting Review, 87(2), 675-703.

Zhou, T., Xie, J., and Li, X. (2016). Financial Reporting Quality and Idiosyncratic Return Volatility: Evidence from China. Emerging Markets Finance and Trade, 53(4), 835847. 